\title{
INCIDENTE DE RESOLUÇÃO DE DEMANDAS REPETITIVAS E TURMAS DE UNIFORMIZAÇÃO DOS JUIZADOS ESPECIAIS
}

\section{Fernando Machado Carboni*}

\section{RESUMO}

Com o Código de Processo Civil de 2015, ocorreu grande controvérsia sobre o órgão competente para julgamento do IRDR em processos do Juizado Especial. Por isso, objetiva-se definir quem possui esta competência: o Tribunal de segunda instância ou a Turma de Uniformização do Juizado Especial. Para tanto, com o uso do método dedutivo, procede-se à análise da legislação, doutrina e jurisprudência. Após esta pesquisa, conclui-se que o incidente será sempre julgado pelo Tribunal de segunda instância, mesmo nos processos de competência exclusiva do Juizado Especial.

Palavras-chave: microssistema; demandas; repetitivas; competência; tribunal.

\section{THE INCIDENT OF MULTIPLE CLAIMS IN THE SAME POINT OF LAW AND THE STANDARDIZATION OF THE SMALL CLAIMS COURTS}

\begin{abstract}
With the Civil Procedure Code of 2015, a great discussion started about the public agency that has jurisdiction to hear the IRDR for lawsuits therein Small Claims Courts. In light of the aforesaid, the aim is to define who has jurisdiction over these cases: The Court of Appeals or the Small Claims second instance judges. For this purpose, by way of the deductive method, follows the analyses of the legislation, literature, and jurisprudence. To conclude that the incident will always be tried be the Court of Appeals, even in the cases in which the Small Claims Court has exclusive jurisdiction.
\end{abstract}

Key-words: microsystem; multiple; claims; jurisdiction; tribunal.

\section{INTRODUÇÃO}

O Código de Processo Civil de 2015 (CPC/2015) criou o Incidente de Resolução de Demandas Repetitivas (IRDR), inspirado em instituto alemão chamado de Musterverfahren. Está previsto nos artigos 976 a 987 do referido Código.

\footnotetext{
* Mestrando em Direito pela Universidade Federal de Santa Catarina - UFSC. Especialista em Direito Processual Civil pela Faculdade de Direito Professor Damásio de Jesus. Especialista em Direito e Gestão Judiciária pela Academia Judicial do TJSC. Graduado em Direito pela UFSC. Juiz de Direito em Santa Catarina, fernando_carboni@yahoo.com.br, Rua XV de Novembro, 580, apto. 1003, Centro, Itajaí/SC.
} 
O artigo 985, I, do CPC/2015, dispõe que o IRDR é aplicável ao Juizado Especial. Entretanto, isso está causando uma grande discussão no meio jurídico sobre qual o órgão competente para o julgamento do IRDR nos processos de competência do Juizado Especial.

Para uma primeira corrente, a decisão será das Turmas de Uniformização do próprio sistema do Juizado Especial. É o que prevê o Enunciado n. 44 da Escola Nacional de Formação de Aperfeiçoamento de Magistrados (ENFAM): “Admite-se o IRDR nos Juizados Especiais, que deverá ser julgado por órgão colegiado de Uniformização do próprio sistema."

Por outro lado, existe uma segunda corrente de que o caso será julgado pelos Tribunais de Justiça (TJ) ou Tribunais Regionais Federais (TRF), conforme Enunciado n. 343 do Fórum Permanente de Processualistas Civis (FPPC): "O incidente de resolução de demandas repetitivas compete a tribunal de justiça ou tribunal regional.”

Em meio a esta divergência, o Tribunal de Justiça do Espírito Santo, por meio da Resolução n. 23/2016, aprovou o Regimento Interno do Colégio Recursal e da Turma de Uniformização de Interpretação de Lei dos Juizados Especiais, com previsão de que o IRDR seja julgado pela Turma de Uniformização.

Com base nisso, em 10-3-2017, julgou-se o IRDR n. 40/2016, mais conhecido como "Caso Samarco", em que muitos autores ajuizaram ações de indenização por dano moral pela interrupção do fornecimento de água potável, em razão da poluição do Rio Doce ocasionada pelo rompimento da barragem de rejeitos de Fundão, localizada no município de Mariana, em Minas Gerais.

Decidiu-se por reconhecer a responsabilidade objetiva da Samarco Mineração S.A., com fixação de dano moral de $\mathrm{R} \$ 1.000,00$ (mil reais) para todas as ações.

Pouco depois, propôs-se no CNJ o Pedido de Providências n. 000262456.2017.2.00.0000, em que se requereu a nulidade da Resolução n. 23/2016 do TJES, bem como dos incidentes julgados com base nela.

Foi assim que em 19-4-2017 deferiu-se a liminar para suspender a eficácia da Resolução n. 23/2016 do TJES, no que diz respeito ao IRDR, IAC e Reclamação, até o julgamento definitivo do Pedido de Providências pelo CNJ.

Trata-se de decisão do Conselheiro Henrique Ávila, que teve como principal fundamento o fato de que as Turmas de Uniformização dos Juizados Especiais não possuem competência para julgamento de IRDR.

O Fórum Nacional dos Juizados Especiais (FONAJE) então, em 19-5-2017, emitiu uma nota técnica, na qual defende que o CNJ reconheça a competência das Turmas de Uniformização dos Juizados Especiais para julgamento de IRDR. 
Foi assim que em 26-6-2017, a Conselheira do CNJ Maria Tereza Uille Gomes revogou a liminar deferida no Pedido de Providências n. 0002624-56.2017.2.00.0000, para que se aguarde o posicionamento do Supremo Tribunal Federal (STF) e Superior Tribunal de Justiça (STJ) sobre o tema.

Assim, surge o grande problema que este artigo visa responder: qual o órgão competente para o julgamento do IRDR nos processos do Juizado Especial: Tribunais de segunda instância ou Turmas de Uniformização?

Entre os objetivos deste artigo, está: estudar os objetivos do CPC/2015; examinar o IRDR; verificar a competência do Juizado Especial; constatar qual o órgão competente para o julgamento do incidente originado de processos do Juizado.

Para alcançar os objetivos, será utilizado o método dedutivo, com estudo da lei, doutrina e jurisprudência. Com obediência aos princípios da Constituição da República Federativa do Brasil de 1988 (CRFB/1988), estudar-se-á os objetivos do CPC/2015 e dos artigos que tratam do IRDR. Na sequência, examinar-se-á a legislação do Juizado Especial, tanto o Estadual, o Federal e o da Fazenda Pública, para ao final, responder à pergunta formulada no problema.

Por fim, a justificativa deste estudo é a importância de se definir a competência para o julgamento do IRDR. Ora, se o incidente for julgado por órgão incompetente, está eivado de nulidade. E como sua decisão tem efeito vinculante para centenas, talvez milhares de demandas repetitivas, os efeitos desta nulidade serão desastrosos.

Por isso este artigo é relevante para contribuir com o debate e ajudar a chegar a uma conclusão definitiva sobre o tema, o que evitará a nulidade de milhares de processos.

\section{OBJETIVOS DO CÓDIGO DE PROCESSO CIVIL DE 2015}

Segundo a exposição de motivos do CPC/2015, o principal objetivo da Comissão de Juristas encarregada de sua elaboração foi tornar o Judiciário mais célere, atento à cláusula constitucional da duração razoável do processo.

Conforme o Presidente da referida Comissão de Juristas, Ministro Luiz Fux (2011, p. 3), “[...] um país que ostenta uma justiça morosa também ostenta uma justiça inacessível.”.

Mas não é possível simplesmente tornar o Judiciário mais rápido. É preciso agilizar, sem perda de qualidade. 
Para isso, segundo a Relatora da Comissão, Tereza Arruda Alvim (2015, p. 1396), é necessário "Gerar uniformidade na jurisprudência, dando sentido prático ao princípio da isonomia e à necessidade de previsibilidade, criando segurança jurídica.”

O CPC/2015 também busca cumprir as normas constitucionais, de modo que os dispositivos do Código serão interpretados sempre conforme a CRFB/1988. É o que consta expressamente no artigo $1^{\circ}$ do $\mathrm{CPC} / 2015$ : “O processo civil será ordenado, disciplinado e interpretado conforme os valores e as normas fundamentais estabelecidos na Constituição da República Federativa do Brasil, observando-se as disposições deste Código.”

E um dos princípios mais importantes da CRFB/1988 é a isonomia, que além de constar no preâmbulo ${ }^{1}$, está no caput do art. $5^{\circ}$, segundo o qual todos são iguais perante a lei, sem distinção de qualquer natureza. Trata-se de cláusula pétrea, que não pode ser excluída nem por emenda constitucional, conforme art. 60, $\S 4^{\circ}$, IV, da CRFB/1988.

E se todos são iguais perante a lei, não faz sentido que casos idênticos sejam julgados de forma diferente, pois decididos por juízes diversos.

Conforme ensina Luiz Guilherme Marinoni (2016b, p. 150):

Partindo-se da premissa, fundante do Estado de Direito - de que os homens são iguais perante a lei e os tribunais - e, portanto, diante das suas decisões -, torna-se um paradoxo admitir que pessoas iguais, com casos iguais, possam obter decisões diferentes do Judiciário. Trata-se, bem vistas as coisas, de um absurdo, curiosamente alimentado por alguns setores.

Outro importante princípio constitucional é a segurança jurídica, que está previsto de forma implícita em alguns dispositivos, como no art. 5, XXXVI, da CRFB/1988, que protege o direito adquirido, o ato jurídico perfeito e a coisa julgada. Também é cláusula pétrea, que não pode ser alterada.

A segurança jurídica tem relação com a "[...] ideia de estabilidade (continuidade, permanência, durabilidade), porque uma ordem jurídica sujeita a variações abruptas não provê condições mínimas para que as pessoas possam se organizar e planejar suas vidas." (MITIDIERO, 2016, p. 23). Também tem relação com previsibilidade, ou seja, é a garantia do cidadão de que os casos futuros serão julgados da mesma forma, sem que cada juiz decida de uma maneira diferente e a pessoa não saiba como pautar sua vida, o que pode ou não fazer, que atitude é conforme o Direito e qual é ilícita. “A variação frívola do que o Judiciário diz

\footnotetext{
${ }^{1}$ Nós, representantes do povo brasileiro, reunidos em Assembleia Nacional Constituinte para instituir um Estado Democrático, destinado a assegurar o exercício dos direitos sociais e individuais, a liberdade, a segurança, o bem-estar, o desenvolvimento, a igualdade e a justiça como valores supremos de uma sociedade fraterna, pluralista e sem preconceitos, fundada na harmonia social e comprometida, na ordem interna e internacional, com a solução pacífica das controvérsias, promulgados, sob a proteção de Deus, a seguinte Constituição da República Federativa do Brasil (grifou-se).
} 
acerca de um texto legal contradiz a segurança jurídica. O cidadão, para poder se desenvolver, tem que conhecer as consequências jurídicas das suas ações e dos comportamentos daqueles com quem convive." (MARINONI, 2016a, p. 65).

E é justamente para contribuir com a igualdade de todos perante a lei e os Tribunais e a segurança jurídica que o CPC/2015 criou figuras para evitar a dispersão excessiva da jurisprudência, como o IRDR. (TEIXEIRA, 2016, p. 367).

\section{CARACTERÍSTICAS DO IRDR}

O IRDR faz parte do microssistema de julgamento de casos repetitivos. Está previsto nos artigos 976 a 987 do CPC/2015.

Segundo o art. 976 do CPC/2015, é cabível sua instauração quando ocorrer, simultaneamente: "I - efetiva repetição de processos que contenham controvérsia sobre a mesma questão unicamente de direito; II - risco de ofensa à isonomia e à segurança jurídica”.

Fácil perceber que o principal objetivo do IRDR é buscar a isonomia e a segurança jurídica. E como visto no item anterior, estes também são objetivos que o CPC/2015 visa alcançar, assim como são importantes princípios constitucionais.

O pedido de instauração do incidente será dirigido ao presidente do Tribunal pelo juiz, pelo relator, pelas partes, pelo Ministério Público ou pela Defensoria Pública (art. 977 do CPC/2015).

Segundo art. 978 do CPC/2015, o julgamento do IRDR será pelo órgão indicado pelo regimento interno dentre os responsáveis pela uniformização da jurisprudência no Tribunal.

Admitido o incidente, o relator determinará a suspensão dos processos, individuais ou coletivos, que tratem de idêntica questão de direito e tramitem na área de jurisdição do Tribunal (Estado se for Justiça Estadual ou região no caso de Justiça Federal), na forma do art. 982 do CPC/2015.

Realizado o julgamento do incidente, a tese jurídica firmada terá efeito vinculante a todos os processos, individuais ou coletivos, que versem sobre a mesma questão de direito e tramitem na área de jurisdição do Tribunal, inclusive os de competência dos Juizados Especiais, conforme disposição expressa do art. 985, I, do CPC/2015. Também será aplicada aos casos futuros. Descumprida a decisão, caberá recurso ou reclamação (art. $985, \S 1^{\circ}$, do CPC/2015).

É possível a revisão desta tese jurídica "pelo mesmo tribunal, de ofício ou mediante requerimento" (art. 986 do CPC/2015). 
Da decisão do incidente, caberá recurso especial e extraordinário, presumindo-se a repercussão geral para este. O julgado proferido pelo STF e pelo STJ terá aplicação em todo território nacional (art. 987 do CPC/2015).

Um ponto que gera muita controvérsia é se o IRDR forma um procedimento-modelo ou se trata de julgamento de causa-piloto.

Segundo esta, alguns processos são selecionados como representativos de controvérsia e afetados, com a suspensão dos demais que tratam de idêntica questão. $O$ julgamento dessas causas-piloto, ao mesmo tempo, fixa a tese jurídica a resolve a lide, o caso concreto. Esse é o sistema do Group Litigation Order inglês.

Já pelo procedimento-modelo, instaura-se um incidente processual, também com a suspensão das causas repetitivas. Julgam-se as questões comuns, em abstrato, com fixação da tese que servirá de modelo aos processos suspensos, sem julgamento do caso concreto. É o sistema adotado no Musterverfahren alemão (CAVALCANTI, 2016).

Enquanto na causa-piloto há unidade cognitiva decisória, pois se julga a causa e fixa a tese ao mesmo tempo, no procedimento-modelo existe cisão cognitiva, com a fixação da tese em abstrato e depois o julgamento do recurso ou processo originário, se for o caso (TEMER, 2016).

Entre estes dois sistemas, entende-se que o IRDR se aproxima mais do procedimento-modelo.

Inicialmente, conforme consta expressamente na Exposição de Motivos do CPC/2015, o IRDR tem inspiração no direito alemão, no chamado Musterverfahren, que significa procedimento-modelo.

Além disso, é um incidente e cabe apenas para questões de direito, conforme art. 976, I, do CPC/2015. É fixada a tese para aplicação em outros casos idênticos. Se fosse causapiloto, seria necessário examinar os fatos para julgar a causa.

Outro argumento para justificar que se aproxima mais de procedimento-modelo é que a desistência ou abandono do processo não impede o exame do mérito do incidente, ou seja, da questão de direito, na forma do art. $976, \S 1^{\circ}$, do CPC/2015. Isso prova que não se pretende julgar a causa-piloto, mas sim fixar a tese jurídica.

Por outro lado, pode-se defender que o IRDR é julgamento de causa-piloto pela redação do parágrafo único do art. 978 do CPC/2015, segundo o qual o órgão que julgar o incidente também decidirá o recurso, reexame necessário ou processo de competência originária. 
Entretanto, existe uma cisão cognitiva, isto é, primeiro se julga o incidente de forma abstrata, com fixação da tese jurídica. Num segundo momento, é decidido o caso concreto, com a análise de todos os pedidos e da causa de pedir, na hipótese de o processo estar pendente de julgamento no Tribunal. Caso contrário, apenas se fixa a tese e devolve-se ao Juízo de origem.

Como ensina Sérgio Luiz de Almeida Ribeiro (2015, p. 191):

É preciso deixar claro que o tribunal não julga o caso concreto em que foi instaurado o IRDR, já que esse mister compete ao órgão jurisdicional de origem. O tribunal apenas roga para si competência para estabelecer a questioiuris que servirá de paradigma para os casos idênticos pendentes e futuros. Em outras palavras, não há um deslocamento de competência para julgamento da causa, apenas a fixação da norma jurídica abstrata pelo tribunal (grifo no original).

Assim, em razão da cisão cognitiva e de que o Tribunal fixa a tese jurídica, concluise que o IRDR se aproxima mais do procedimento-modelo do que da causa-piloto.

\section{COMPETÊNCIA DO JUIZADO ESPECIAL}

O microssistema do Juizado Especial tem fundamento no art. 98, I, da CRFB/1988, que prevê a competência para julgamento e execução das causas cíveis de menor complexidade. Com base neste dispositivo, foi editada a Lei n. 9.099/1995, que trata dos Juizados Especiais Cíveis e Criminais nos Estados, Distrito Federal e Territórios. Posteriormente, editou-se a Lei n. 10.259/2001, que dispõe sobre os Juizados Especiais Federais (JEF). Mais recentemente, a Lei n. 12.153/2009, que instituiu os Juizados Especiais da Fazenda Pública.

Será analisada a competência cível em cada uma das três leis que compõem o microssistema do Juizado Especial.

O art. $3^{\circ}$ da Lei n. 9.099/1995 prevê duplo critério para fixação da competência dos Juizados Especiais Cíveis dos Estados, Distrito Federal e Territórios (JEC): quantitativo e qualitativo. Este diz respeito à matéria e aquele ao valor da controvérsia (FIGUEIRA JÚNIOR; TOURINHO NETO, 2009, p. 85).

Quanto ao valor, o Juizado Especial é competente para o julgamento de causas de até 40 (quarenta) salários mínimos. Concernente ao critério material, a competência é para as causas do inciso II do art. 275 do CPC/1973 (procedimento sumário) e despejo para uso próprio. 
Importante destacar que mesmo com a revogação do CPC/1973, o JEC continua competente para o julgamento das causas previstas no art. 275, II, de referido Código, por força o art. 1.063 do CPC/2015, in verbis: "Até a edição de lei específica, os juizados especiais cíveis previstos na Lei n. 9.099, de 26 de setembro de 1995, continuam competentes para o processamento e julgamento das causas previstas no art. 275, inciso II, da Lei n. 5.869, de 11 de janeiro de 1973."

Nos primeiros anos após o surgimento da Lei n. 9.099/1995, houve grande controvérsia a respeito de se a competência do JEC é opcional ou obrigatória. No início, a doutrina inclinou-se por ser obrigatória, de modo que se a causa fosse prevista em lei como de competência do JEC, o autor não poderia optar pelo rito comum.

Entretanto, hoje é amplamente majoritário na doutrina e na jurisprudência o entendimento de que a competência pelo JEC é opcional (CÂMARA, 2010).

Nesse sentido, o Enunciado n. 1 do FONAJE: "O exercício do direito de ação no Juizado Especial Cível é facultativo para o autor."

Este também é o entendimento pacificado no Superior Tribunal de Justiça (STJ). ${ }^{2}$ E se é uma faculdade do autor optar por ajuizar sua ação no JEC, significa que um mesmo fato pode gerar demandas repetitivas no Juizado Especial e no Juízo Comum, com recursos à Turma Recursal e ao TJ, respectivamente.

Por outro lado, quanto ao JEF, o art. $3^{\text {o }}$ da Lei n. 10.259/2001 adota como critério para fixar a competência o valor das demandas, que é de até 60 (sessenta) salários mínimos. O $\S 3^{\circ}$ do art. $3^{\circ}$ da mesma Lei dispõe que onde estiver instalada Vara do Juizado, a competência é absoluta. De outro modo, nas demais hipóteses, como Juizados adjuntos, itinerantes, etc., a competência é relativa (FIGUEIRA JÚNIOR; TOURINHO NETO, 2007).

Dessa forma, onde não há Vara do Juizado Especial instalada, é opção do autor seguir este procedimento, de modo que um mesmo fato pode gerar demandas repetitivas no Juízo Comum, com recurso ao TRF, bem como no JEF, com impugnação dirigida à Turma de Recursos.

Já nos locais com Vara privativa instalada, a competência é absoluta, de modo que o autor não pode optar. Não obstante, se um mesmo fato gerar causas com valores inferiores e

\footnotetext{
2 “[...] 3. O Superior Tribunal de Justiça possui entendimento de que 'o processamento da ação perante o Juizado Especial é opção do autor, que pode, se preferir, ajuizar sua demanda perante a Justiça Comum' (REsp. 173.205/SP, Relator Ministro Cesar Asfor Rocha, Quarta Turma, DJ 14.6.1999). A propósito: REsp 331.891/DF, Rel. Ministro Antônio de Pádua Ribeiro, Terceira Turma, 21.3.2002; REsp 146.189/RJ, Rel. Ministro Barros Monteiro, Quarta Turma, DJ 29.6.1998. 4. O art. $3^{\circ}, \S 3^{\circ}$, da Lei 9.099/1995 e o art. $1^{\circ}$ da Lei Estadual 10.675/1996 permitem que a demanda seja ajuizada no Juizado Especial ou na Justiça Comum, sendo essa uma decisão da parte. 5. Recurso Ordinário provido." (STJ, Segunda Turma, Recurso Ordinário em Mandado de Segurança n. 53.227/RS, rel. Min. Herman Benjamin, julgado em 26-7-2017).
} 
superiores a 60 (sessenta) salários mínimos, também haverá demandas repetitivas no Juizado Especial e no Juízo Comum.

Assim, só haverá demandas exclusivamente no JEF se todas as causas repetitivas originadas do mesmo fato forem de valor inferior a 60 (sessenta) salários mínimos e houver Vara privativa instalada no local.

Quanto ao Juizado Especial da Fazenda Pública, também segue a regra da competência para as ações com valor inferior a 60 (sessenta) salários mínimos, conforme art. $2^{\circ}$, caput, da Lei n. 12.153/2009. Exige-se apenas que seja parte demandada entidade pública estadual, distrital ou municipal. E da mesma forma que no JEF, consta que onde houver instalada Vara do Juizado Especial da Fazenda Pública, a competência será absoluta, conforme art. $2^{\circ}$, $\S 4^{\circ}$, da Lei n. 12.153/2009 (CÂMARA, 2010).

Assim, um mesmo fato também pode gerar demandas repetitivas no Juizado Especial da Fazenda Pública e no Juízo Comum, caso algumas ações ultrapassem 60 (sessenta) salários mínimos e outras não. O mesmo ocorre na hipótese de ações propostas em comarcas que não tenham instalada uma Vara privativa do Juizado Especial da Fazenda Pública, o que é a realidade da maioria das comarcas.

Portanto, constata-se que nas três esferas do Juizado Especial existentes no Brasil, quais sejam, dos Estados, Federal e da Fazenda Pública, um mesmo fato pode originar demandas cíveis no Juízo Comum e no Juizado.

No julgamento relatado na introdução, por exemplo, que é o "Caso Samarco", as pessoas atingidas pelo desastre ambiental podem ajuizar suas demandas nas Varas Cíveis ou no JEC. Da sentença proferida, no primeiro caso caberá apelação ao Tribunal de Justiça, enquanto que no segundo, recurso inominado à Turma Recursal.

\section{JUIZADO ESPECIAL E COMPETÊNCIA PARA JULGAMENTO DO IRDR}

Apesar de o CPC/2015 não prever a competência das Turmas de Uniformização dos Juizados Especiais para julgamento do IRDR, também não há proibição expressa, o que faz muitos autores defenderem ser possível estabelecer esta competência.

Não obstante, como já analisado na seção 3, em muitos dispositivos, o CPC/2015 faz menção ao termo "Tribunal" para julgamento do IRDR, in verbis:

Art. 977. O pedido de instauração do incidente será dirigido ao presidente de tribunal: Art. 978. O julgamento do incidente caberá ao órgão indicado pelo regimento interno dentre aqueles responsáveis pela uniformização de jurisprudência do tribunal. 
Art. 986. A revisão da tese jurídica firmada no incidente far-se-á pelo mesmo tribunal [...] (grifou-se).

Assim, com a redação dos dispositivos acima, por uma interpretação gramatical, não há como concluir que a competência para decidir o IRDR seja de outro órgão que não o Tribunal, conforme assinala Marinoni (2016a, p. 70):

O art. 977 do CPC/2015 deixa claro que a competência para julgar a questão prejudicial posta no incidente é do tribunal - de Justiça, Regional Federal ou Regional do Trabalho -, seja quando as demandas repetitivas que dão origem ao delineamento da questão estão em primeiro grau de jurisdição, seja quando já estão no tribunal, em vista da interposição de recursos de apelação.

É o que consta também na Exposição de Motivos do CPC/2015: "É instaurado perante o Tribunal local, por iniciativa do juiz, do MP, das partes, da Defensoria Pública ou pelo próprio Relator.” (grifou-se).

E como competência é matéria de direito processual, somente lei federal pode modificá-la, conforme art. 22, I, da CRFB/1988. Nem medida provisória pode dispor sobre direito processual, por vedação expressa do art. 62, § 1º I, “b”, da CRFB/1988.

Dessa forma, se apenas lei federal pode estabelecer a competência das Turmas Recursais ou de Uniformização para julgamento do IRDR, conclui-se que é inconstitucional fazer esta previsão por meio de resolução ou regimento interno de Tribunal (UBIALI, 2015), conforme fez o Tribunal de Justiça do Espírito Santo, que resultou no julgamento do "Caso Samarco" pela Turma de Uniformização do JEC.

De outro modo, alguns autores defendem que o Juizado Especial não é subordinado às decisões dos Tribunais de segunda instância, por força do art. 98, I, da CRFB/1988, o qual prevê que o julgamento de recursos será feito por Turmas de juízes de primeiro grau. Assim, o juiz do Juizado Especial não seria obrigado a seguir a decisão proferida em IRDR pelo Tribunal de segunda instância (CAVALCANTI, 2016).

Também fundamentam este ponto de vista em decisões judiciais de que compete à Turma Recursal e não ao TJ ou TRF processar e julgar mandado de segurança impetrado de ato de juiz de primeira instância do JEC como substitutivo de recurso, ${ }^{3}$ de modo que também compete à Turma Recursal ou de Uniformização julgar o IRDR. Apesar de que o próprio STF já julgou, após reconhecer a repercussão geral, pelo não cabimento de mandado de segurança das decisões interlocutórias exaradas em processos do JEC. ${ }^{4}$

\footnotetext{
${ }^{3}$ Recurso Extraordinário n. 586.789, Pleno do STF, Rel. Min. Ricardo Lewandowski, julgado em 16-11-2011.

${ }^{4}$ Repercussão Geral no Recurso Extraordinário n. 576.847, Pleno do STF, Rel. Min. Eros Roberto Grau, julgado em $1^{\circ}-5-2008$.
} 
Ocorre que, apesar de não haver subordinação entre juiz do Juizado Especial e TJ ou TRF, existem várias hipóteses em que Tribunais controlam atos de Juízos a eles não vinculados. É o caso do TRF dirimir conflito de competência entre JEF e Juízo Federal, conforme súmula n. 428 do STJ. ${ }^{5}$ Este Tribunal Superior, aliás, julga conflito de competência entre Juízo Trabalhista e Juízo Comum, apesar de o juiz do trabalho não ser vinculado ao STJ. 6

Outro importante exemplo é que apesar de os Juizados Especiais não serem subordinados ao STJ, tanto que não cabe recurso especial, segundo súmula n. 203 de referido Tribunal, $^{7}$ os juízes do Juizado devem seguir as decisões do STJ.

Prova disso é que as leis do JEF e do Juizado Especial da Fazenda Pública preveem que o STJ faz parte dos mecanismos de uniformização de jurisprudência. $\mathrm{O} \S 4^{\circ}$ do art. 14 da Lei n. 10.259/2001 dispõe que se houver divergência entre a Turma Nacional de Uniformização (TNU) e o STJ, cabe a este dirimir a controvérsia. Da mesma forma, o art. 18, $\S 3^{\circ}$, da Lei n. 12.152/2009 estabelece que, nos Juizados Especiais da Fazenda Pública, se as Turmas Recursais de diferentes Estados derem à lei federal interpretações divergentes, cabe ao STJ dar a palavra final (MENDES; ROMANO NETO, 2015).

E mesmo nos Juizados Especiais Estaduais, o STF assentou a necessidade de uniformização da jurisprudência, de modo que cabe reclamação ao STJ se o juiz ou Turma Recursal do Juizado Especial não respeitar a decisão deste Tribunal, com fundamento no art. 105, I, “f”, da CRFB/1988. ${ }^{8}$

Em razão desta decisão, o STJ publicou a Resolução n. 12/2009 para disciplinar referida reclamação. Posteriormente editou a Resolução n. 2/2016, o qual prevê que cabe aos Tribunais de Justiça processar e julgar as reclamações destinadas a dirimir controvérsia entre Turma Recursal Estadual e a jurisprudência do STJ consolidada em IAC, IRDR, recurso repetitivo e súmula.

Então, se o STF e o STJ já assentaram que os juízes do Juizado Especial devem seguir as decisões deste Tribunal proferidos em IRDR e outros casos, apesar de não serem a ele subordinados, pelo mesmo raciocínio, os juízes do JEC também devem seguir as decisões

\footnotetext{
${ }^{5}$ Súmula n. 428 do STJ. Compete ao Tribunal Regional Federal decidir os conflitos de competência entre juizado especial federal e juízo federal da mesma seção judiciária.

${ }^{6}$ Agravo Regimental no Conflito de Competência n. 130.453/PB, Primeira Seção do STJ, Rel. Min. Napoleão Nunes Maia Filho, julgado em 11-10-2017.

${ }^{7}$ Súmula n. 203 do STJ: Não cabe recurso especial contra decisão proferida por órgão de segundo grau dos Juizados Especiais.

${ }^{8}$ Embargos de Declaração do Recurso Extraordinário n. 571.572/BA, Pleno do STF, Rel. Min. Ellen Gracie, julgado em 26-8-2009.
} 
proferidas pelos Tribunais de segunda instância em IRDR, mesmo não sendo subordinados a eles.

Importante, ainda, fazer referência que o microssistema do Juizado Especial possui mecanismos próprios para pacificar a jurisprudência, mas que apresentam algumas deficiências.

O primeiro mecanismo foi previsto na Lei n. 10.259/2001 para o JEF. O art. 14 de referida Lei criou o pedido de uniformização de interpretação de lei, cabível para decisões divergentes sobre questões de direito material proferidas por Turmas Recursais.

Se as Turmas forem da mesma região da Justiça Federal, o julgamento ocorrerá da reunião das Turmas em conflito, sob a presidência do juiz coordenador. Se forem Turmas de regiões diferentes ou alguma decisão contrariar súmula ou jurisprudência dominante do STJ, o pedido será julgado pela Turma Nacional de Uniformização (TNU), integrada por juízes de Turmas Recursais e presidida pelo Coordenador da Justiça Federal. E se a decisão da TNU for contrária ao STJ, sempre no direito material, cabe a este dar a palavra final.

Da mesma forma, a Lei n. 12.153/2009, em seu art. 18, criou um mecanismo de pacificação da jurisprudência do âmbito do Juizado Especial da Fazenda Pública. Também é chamado de pedido de uniformização de interpretação de lei, cabível em caso de divergência entre decisões de Turmas Recursais sobre direito material.

Se forem do mesmo Estado as Turmas, será julgado pela reunião das Turmas em conflito, sob a presidência de desembargador indicado pelo TJ. Quando de diferentes Estados, ou se a decisão contrariar súmula do STJ, a decisão é deste Tribunal.

Por outro lado, a Lei n. 9.099/1995 nada previu sobre a uniformização da jurisprudência no Juizado Especial Estadual, apesar de alguns Estados criarem Turmas de Uniformização com base nos artigos 18 e 20 da Lei n. 12.153/2009. De qualquer forma, cabe reclamação em caso de violação de decisão do STJ, conforme visto acima.

Estes são os mecanismos existentes de uniformização da jurisprudência no microssistema dos Juizados Especiais, para os quais são apontadas três deficiências: 1 - não existe previsão legal expressa para os Juizados Estaduais; 2 - abrange apenas o direito material, não o processual; 3 - ausência de mecanismos para pacificar a jurisprudência entre Juizados Especiais e Tribunais de Justiça ou Regionais Federais (MENDES, ROMANO NETO, 2015).

O IRDR resolve essas três deficiências, pois: 1 - aplica-se aos Juizados Especiais Estaduais; 2 - cabe para direito material e processual; 3 - caso julgado pelos Tribunais de 
segunda instância, é um mecanismo para unificar a jurisprudência entre Juizado Especial e Tribunais de Justiça ou Regionais Federais.

Se admitido que o IRDR seja julgado pelas Turmas de Uniformização do Juizado Especial, ele gerará efeito contrário a este item três, pois servirá para aumentar a divergência jurisprudencial, de modo que será possível julgar um incidente na Turma de Uniformização e outro no Tribunal de segunda instância, ambos sobre a mesma matéria.

E é justamente aqui que reside o maior problema em se admitir o julgamento de IRDR por Turma de Uniformização. É que segundo visto na seção 2 deste artigo, o principal objetivo do CPC/2015 foi tornar o Judiciário mais célere, conforme o princípio constitucional da duração razoável do processo. Para isso, o Código busca uniformizar a jurisprudência, o que traz mais isonomia e segurança jurídica, dois princípios considerados dos mais importantes na CRFB/1988.

E um dos instrumentos usados para isso foi justamente o IRDR, que por disposição expressa do art. 976, II, do CPC/2015, é utilizado quando houver risco de ofensa à isonomia e à segurança jurídica, conforme estudado na seção n. 3 deste artigo.

Não obstante isso, segundo examinado na seção 4, um fato pode gerar demandas repetitivas no Juízo Comum e no microssistema do Juizado Especial, seja no Estadual, Federal ou da Fazenda Pública.

Com isso, haverá dois órgãos aptos a uniformizar a jurisprudência por meio do IRDR, que é a Turma de Uniformização e o Tribunal de segunda instância, o que poderá resultar em decisões divergentes numa mesma base territorial e para os mesmos jurisdicionados. Tal fato resultará em quebra da isonomia e da segurança jurídica, causada ironicamente por um incidente e um Código que buscam evitar que isso ocorra. É um total contrassenso, que contraria toda a lógica criada pelo CPC/2015.

O FONAJE emitiu uma nota técnica em 19-5-2017 na qual defende que nesta hipótese a divergência seja dirimida pelo Órgão Especial ou Pleno do TJ ou TRF, mas isso esbarra mais uma vez no art. 22, I, da CRFB/1988, pois se cria por resolução ou regimento um incidente e uma competência não previstos em lei federal.

Existe ainda a possibilidade de uma matéria ser exclusiva do Juizado Especial e não poder ser resolvida por seus mecanismos de uniformização da jurisprudência, como uma divergência de natureza exclusivamente processual.

Se o IRDR for entendido como causa-piloto, a matéria nunca chegará ao Tribunal de segunda instância, de modo que não é cabível a instauração deste incidente. 
Mas se for considerado que o incidente mais se aproxima de um procedimentomodelo, como se concluiu na seção 3 deste artigo, é possível ao juiz do Juizado suscitar o IRDR no Tribunal por meio de ofício (art. 977, I, do CPC/2015), conforme enunciado n. 21 da ENFAM: "O IRDR pode ser suscitado com base em demandas repetitivas em curso nos juizados especiais".

Ao decidir o IRDR, o TJ ou TRF apenas julgará a questão comum, com fixação da tese, que será aplicada a todos os processos da área de jurisdição do respectivo Tribunal, inclusive no Juizado Especial (art. 985, I, do CPC/2015), sem julgar o caso concreto. "Diz-se isso pois o IRDR promoverá uma cisão no procedimento do processo em que ele foi instaurado em que o tribunal estabelecerá a questio iuris abstrata, enquanto, que o caso concreto ficará a cargo do juízo de origem.” (grifo no original) (RIBEIRO, 2015, p. 192).

Foi o que fez o TRF da $4^{\text {a }}$ Região ao decidir o IRDR n. 5033207-91.2016.4.04.0000, que trata da fixação do valor da causa em relações de trato sucessivo com parcelas vencidas e vincendas, bem como o órgão competente quando ocorre renúncia ao excedente a 60 (sessenta) salários mínimos. O processo de origem tramitava no JEF. O autor suscitou o incidente no TRF da $4^{a}$ Região, que o admitiu e julgou o mérito.

Perceba-se que é matéria processual, de modo que não poderia ser resolvida pelos mecanismos próprios do Juizado Especial.

E se fosse julgado o IRDR pelas Turmas Recursais ou pela Turma de Uniformização, haveria o risco de outro incidente ser julgado pelo TRF de forma divergente, o que ofenderia a isonomia e a segurança jurídica.

Da maneira como ocorreu, o incidente foi julgado pelo Tribunal, que fixou a tese jurídica em abstrato, a qual é aplicável ao Juízo Comum e ao JEF, exatamente como defendido neste artigo.

Por tudo o que foi visto, especialmente os princípios da isonomia e da segurança jurídica, a melhor solução é que o IRDR seja julgado apenas pelos Tribunais de segunda instância e não pelas Turmas de Uniformização dos Juizados Especiais. Esta será a melhor maneira de se cumprir os objetivos do CPC/2015 e do próprio IRDR.

\section{CONCLUSÃO}

Constatou-se na segunda seção deste artigo que o principal objetivo da Comissão de Juristas encarregada de elaborar o CPC/2015 foi tornar o Judiciário mais célere. Para isso, 
entenderam ser necessário uniformidade da jurisprudência, o que trará mais isonomia e segurança jurídica.

$\mathrm{Na}$ terceira seção verificou-se que um dos principais instrumentos do CPC/2015 para se alcançar a isonomia e a segurança jurídica é o IRDR. Ao se examinar este incidente, com suas principais características, concluiu-se que ele mais se aproxima da forma de procedimento-modelo do que de causa-piloto, uma vez que há cisão cognitiva, de modo que o IRDR apenas decide a questão comum. Somente depois é que se julga o caso concreto, na hipótese de o processo estar pendente de julgamento no Tribunal. Caso contrário, apenas se fixa a tese e devolve-se ao Juízo de origem.

Examinou-se na quarta seção que o microssistema do Juizado Especial é formado pelo JEC, JEF e Juizado Especial da Fazenda Pública. E com o estudo da competência de cada um, constatou-se que em qualquer uma das três esferas, um mesmo fato pode gerar demandas repetidas neste microssistema e no Juízo Comum, com recursos à Turma Recursal e ao Tribunal de Justiça ou Regional Federal.

Assim, após uma interpretação gramatical dos artigos do CPC/2015, especialmente os 977, 978 e 986, não há como concluir que a competência para decidir o IRDR seja de outro órgão que não do Tribunal de segunda instância. Isso consta, inclusive, na Exposição de Motivos de referido Código.

E como competência é matéria processual, só pode ser fixada por lei federal, nunca por resolução ou regimento interno, conforme art. 22, I, da CRFB/1988.

Também se concluiu que a obrigatoriedade de os juízes do Juizado Especial seguirem o IRDR julgado pelo TJ ou TRF não viola o art. 98, I, da CRFB/1988, pois existem várias hipóteses em que Tribunais controlam atos de Juízos a eles não vinculados. É o caso do cabimento de reclamação ao STJ se o juiz ou Turma Recursal do JEC não respeitar a decisão deste Tribunal, mesmo não sendo o Juizado subordinado ao STJ.

Mas não se chega a esta conclusão apenas pela interpretação gramatical. O principal motivo pelo qual o IRDR não pode ser julgado pelas Turmas de Uniformização do Juizado é que isso violaria a isonomia e a segurança jurídica, que são importantes princípios constitucionais e objetivos buscados pelo CPC/2015 para tornar o Judiciário mais célere. E o IRDR é um dos instrumentos para se alcançar estes objetivos.

Ocorre que se um fato pode gerar demandas repetitivas no Juízo Comum e no JEC, haverá dois órgãos aptos a uniformizar a jurisprudência por meio do IRDR, que é a Turma de Uniformização e o Tribunal local, que poderá resultar em decisões divergentes numa mesma base territorial e para os mesmos jurisdicionados. 
Por tudo o que foi visto acima, concluiu-se que o órgão competente para o julgamento do IRDR é o Tribunal de segunda instância, não a Turma de Uniformização. Mesmo nos casos de competência exclusiva do Juizado, pois como o incidente mais se aproxima do procedimento-modelo, uma vez suscitado, o Tribunal apenas decidirá a questão comum, com fixação de uma tese jurídica, cabendo aos juízes aplicá-la aos casos concretos.

Assim, sendo, respondeu-se ao problema formulado na introdução e alcançaram-se os objetivos da pesquisa.

\section{REFERÊNCIAS BIBLIOGRÁFICAS}

ABBOUD, Georges, CAVALCANTI, Marcos de Araújo. Inconstitucionalidades do incidente de resolução de demandas repetitivas (IRDR) e os riscos ao sistema decisório. Revista de Processo, São Paulo, v. 40, n. 240, p. 221-242, fev. 2015.

BRASIL. CÉSPEDES, Livia; ROCHA, Fabiana Dias da (Col). Vade mecum Saraiva compacto. 19. ed. São Paulo: Saraiva, 2018.

CABRAL, Antônio do Passo. O novo procedimento-modelo (Musterverfahren) alemão: uma alternativa às ações coletivas. Revista de Processo, São Paulo, v. 32, n. 147, p. 123-146, maio/2007.

CÂMARA, Alexandre Freitas. Juizado especiais cíveis estaduais, federais e da fazenda púbica: uma abordagem crítica. 6. ed. Rio de Janeiro: Lumen Juris, 2010.

CAVALCANTI, Marcos de Araújo. Incidente de Resolução de Demandas Repetitivas. São Paulo: Revista dos Tribunais, 2016.

FIGUEIRA JÚNIOR, Joel Dias; TOURINHO NETO, Fernando da Costa. Juizados Especiais estaduais cíveis e criminais: comentários à Lei 9.099/1995. 6. ed. rev., atual. e ampl. São Paulo: Revista dos Tribunais, 2009.

FIGUEIRA JÚNIOR, Joel Dias; TOURINHO NETO, Fernando da Costa. Juizados Especiais federais cíveis e criminais: comentários à Lei 10.259, de 10.07.2001. 2. ed. rev., atual. e ampl. São Paulo: Revista dos Tribunais, 2007.

FIGUEIRA JÚNIOR, Joel Dias. Juizados Especiais da fazenda pública: comentários à Lei 12.153 de dezembro de 2009. São Paulo: Revista dos Tribunais, 2010.

FUX, Luiz. O novo processo civil. In: FUX, Luiz (Coord.). O novo processo civil brasileiro: direito em expectativa. Rio de Janeiro: Forense, 2011.

MARINONI, Luiz Guilherme. Incidente de Resolução de Demandas Repetitivas: decisão de questão idêntica x precedente. São Paulo: Revista dos Tribunais, 2016a. 
Precedentes obrigatórios. 5. ed. rev., atual. e ampl. São Paulo: Revista dos Tribunais, 2016b.

MENDES, Aluisio Gonçalves de Castro; ROMANO NETO, Odilon. Análise da relação entre o novo incidente de resolução de demandas repetitivas e o microssistema dos juizados especiais. Revista de Processo, São Paulo, v. 40, n. 245, p. 275-310, jul. 2015.

MENDES, Aluisio Gonçalves de Castro. Incidente de resolução de demandas repetitivas: sistematização, análise e interpretação do novo instituto processual. Rio de Janeiro: Forense, 2017.

MEZZAROBA, Orides; MONTEIRO, Cláudia Servilha. Manual de metodologia da pesquisa no direito. 6. ed. São Paulo: Saraiva, 2014.

MITIDIERO, Daniel. Precedentes: da persuasão à vinculação. São Paulo: Revista dos Tribunais, 2016.

RIBEIRO, Sérgio Luiz de Almeida. Incidente de Resolução de Demandas Repetitivas IRDR: o procedimento padrão tupiniquim e suas peculiaridades (breves reflexões). Revista Brasileira de Direito Processual - RBDPRO, Belo Horizonte, ano 23, n. 92, p. 185-208, out/dez. 2015.

TEIXEIRA, Guilherme Puchalski. Incidente de resolução de demandas repetitivas: projeções em torno de sua eficiência. Revista de Processo, São Paulo, v. 41, n. 251, p. 359-387, jan. 2016.

TEMER, Sofia Orberg. Incidente de Resolução de Demandas Repetitiva. Juspodvm: Salvador, 2016.

TESHEINER, José Maria Rosa, VIAFORE, Daniele. O incidente de resolução de demandas repetitivas no novo Código de Processo Civil. Revista Brasileira de Direito Processual RBDPro, Belo Horizonte, v. 23, n. 91, p. 171-224, jul./set. 2015.

VIAFORE, Daniele. As semelhanças e as diferenças entre o procedimento-modelo alemão Musterverfahren e a proposta de um "incidente de resolução de demandas repetitivas" no PL 8.045/2010. Revista de Processo, São Paulo, v. 38, n. 217, p. 257-308, mar/2013.

UBIALI, Janice Goulart Garcia. O incidente de resolução de demandas repetitivas e os juizados especiais. In: LINHARES, Erick (Org). Juizados especiais cíveis e o novo CPC. Curitiba: Juruá, 2015.

WAMBIER, Tereza Arruda Alvim; CONCEIÇÃO, Maria Lúcia Lins; RIBEIRO, Leonardo Ferres da Silva; MELLO, Rogério Licastro Torres de. Primeiros Comentários ao Novo Código de Processo Civil: artigo por artigo. São Paulo: Revista dos Tribunais, 2015. 